\title{
VOLATILITY MODELLING IN THE FOREX MARKET: AN EMPIRICAL EVALUATION
}

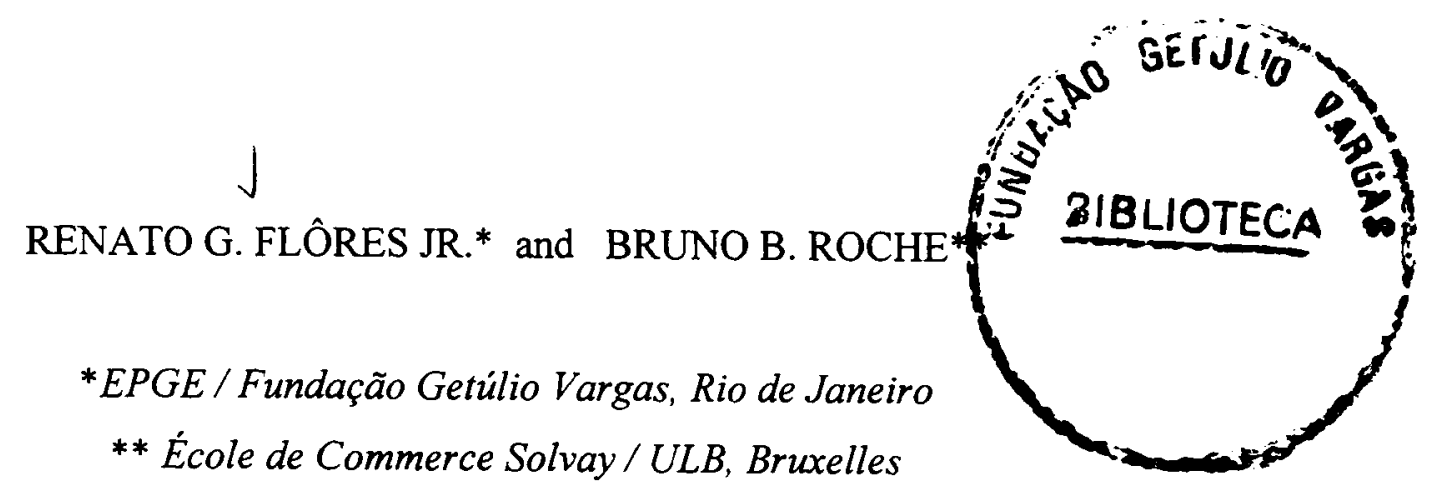

(October, 1999)

We compare three frequently used volatility modelling techniques: GARCH, Markovian switching and cumulative daily volatility models. Our primary goal is to highlight a practical and systematic way to measure the relative effectiveness of these techniques. Evaluation comprises the analysis of the validity of the statistical requirements of the various models and their performance in simple options hedging strategies. The latter puts them to test in a "real life" application. Though there was not much difference between the three techniques, a tendency in favour of the cumulative daily volatility estimates, based on tick data, seems clear. As the improvement is not very big, the message for the practitioner - out of the restricted evidence of our experiment - is that he will probably not be losing much if working with the Markovian switching method. This highlights that, in terms of volatility estimation, no clear winner exists among the more sophisticated techniques.

Keywords: volatility modelling, GARCH, Markovian switching, cumulative daily volatility, standardised returns, volatility hedging. 



\section{INTRODUCTION}

This paper presents an empirical comparison of frequently used volatility modelling techniques. Our primary goal is to highlight a practical and systematic way to measure the relative effectiveness of these techniques. We evaluate the quality of GARCH, Markovian switching and cumulative daily volatility (cdVol) models, based on daily and intra-day data, in forecasting the daily volatility of an exchange rate data series. The analysis considers both the models' residuals and the performance of simple options hedging strategies. The former deals with the validity of the statistical requirements of the various models, while the latter puts them to test in a (close to) "real life" application. The residuals' analysis deals with the distributional properties of the standardised returns - using the continuously updated volatilities - which are usually assumed to be normal. This provides a uniform framework to compare models which have a more complete statistical structure with others, less complete, where a residual term, in the classical sense, does not exist. While GARCH and Markovian switching structures belong to the first class, cdVol computations should be included in the second.

Though we have not found much difference between the techniques tested, GARCH estimates performed poorly in the options hedging and a tendency in favour of the cumulative daily volatility estimates, based on tick data, seems clear. Given that cdVol procedures use much more information than the other alternatives, this might have been expected.

As the improvement is not very big, and periods of market inefficiency were detected, the message for the practitioner - out of the restricted evidence of our experiment -, is that, if either access to or manipulation of tick data is difficult, he might not be losing much if working with the other two methods. Notwithstanding, as a second best, results slightly favour the Markovian switching method.

The lack of a conclusive winner draws attention to the need of more studies of this kind. Indeed, we still are at crossroads in terms of volatility estimation, no clear optimum existing among the more sophisticated techniques.

The structure of the work is as follows. The next two sections describe the data used and then briefly review the volatility modelling methods compared. Section 4 comments 
upon the two evaluation strategies, while section 5 presents the empirical results. The final section concludes.

\section{DATA DESCRIPTION}

We use daily observations (recorded at 10pm GMT) of the Deutsche Mark (DEM) against the US dollar (USD), from October 1995 to October 1998 (784 trading days in total). We also use interbank tick-by-tick quotes of foreign exchange (forex) rates, supplied by Reuters via Olsen \& Associates, and over-the-counter currency options data, interbank, $10 \mathrm{pm}, 1 \mathrm{month}$, at-the-money implied volatility.

\subsection{Intraday data and the foreign exchange interbank market}

The interbank market, in contrast with other exchange markets, has no geographical limitations (currencies are traded all over the world) and no trading-hours scheme (currencies are traded all around-the-clock): it is truly a 24hours, 7days-a-week market. Naturally, there are significant intraday, intraweek and intrayear seasonal patterns (see Figures 1 and 2), explained respectively by the time zone effect (in the case of the USD/DEM rate, the European and the US time zones are the most active ones), the low activity exhibited during weekends and some universal bank holidays (eg: Christmas, New Year). Some other factors such as the release of economic indicators by central banks may also have an effect on the structural seasonality observed in foreign exchange markets.

Forex traders negotiate deals and agree transactions over the telephone, trading prices and volumes being not known to third parties. The data we use in this study are the quotes from a large data supplier (Reuters). These quotes are provided by marketmakers and conveyed to data subscribers terminals. They are meant to be indicative, providing a general indication of where an exchange rate stands at a given time. Though not necessarily representing the actual rate at which transactions really took place, these indicative quotes are felt as being fairly accurate and matching the true prices experienced in the market. ${ }^{1}$ Moreover, in order to avoid dealing with the bid-ask issue, inherent to most high frequency data (see, for instance, Chapter 3 in Campbell et al.

\footnotetext{
'The professionalism of the market-makers (whose credibility and reputation depend on their relationship with other market participants) usually keeps the market in good working order.
} 
(1997)), use was made in this study of the bid series only, generally regarded as a more consistent set of observations.

Further description of questions related to intra-day data in forex markets can be found in Baillie and Bollerslev (1989), Goodhart and Figliuoli (1991), Müller et al. (1997) and Schnidrig and Würtz (1995), among others.

\subsection{Exchange rate returns}

Traditionally, returns on forex series are continuously compounded returns. They are calculated as the difference in natural logarithm of the exchange rate value $S_{t}$ for two consecutive observations : $r_{t}=100\left[\ln \left(S_{t}\right)-\ln \left(S_{t-1}\right)\right]$.

Table 1 shows the basic descriptive statistics for the USD/DEM foreign exchange returns, for the ticks and daily data. There is an enormous difference between the first two moments of the series, confirming the dramatic effect of time aggregation, Ghysels et al. (1998). Daily data are quite spread out, with a coefficient of variation (CV) of 26.65 , but tick data are considerably more, with a CV 274 times higher. Moreover, their kurtosis is also much higher.

The ticks series allow the examination of intra-day, intra-week and intra-year (or inter-month) patterns, Guillaume et al. (1997). Figures 1 and 2 show, respectively, the intra-day and intra-week patterns.

Table 1. Descriptive statistics of the daily and tick-by-tick returns.

\begin{tabular}{|l|r|r|r|r|r|r|r|}
\hline & Nb of obs. & Mean & St. Dev. & Skewness & Kurtosis & Acf(1) & Acf(2) \\
\hline Tick-by-tick & $5,586,417$ & $2.8 \mathrm{E}-8$ & $2.04 \mathrm{E}-4$ & -0.09 & 13.34 & $-46.3 \%$ & $0.4 \%$ \\
\hline Daily & 784 & $2.0 \mathrm{E}-4$ & $0.53 \mathrm{E}-2$ & -0.23 & 4.17 & & \\
\hline
\end{tabular}

\subsection{Implied volatility - the Black-Scholes model}

The language and conventions of currency option trading are drawn from the Black-Scholes-Merton model, Black and Scholes (1973), even though neither traders nor academics believe in its literal truth. The model assumes that the spot exchange rate follows a geometric Brownian motion, in which the constant term of the drift equals $\mathrm{r}-\mathrm{r}^{*}$, the difference between the risk-free, continuously compounded domestic and 
foreign interest rates. The drift and the constant volatility parameter $\sigma$ are supposed known.

Logarithmic exchange rate returns are then normally distributed, and formulas for European put and call values can be obtained. That for a call is

$$
v\left(S_{t}, \tau, X, \sigma, r, r^{*}\right)=e^{-r^{*} \tau} S_{t} \Phi\left[\frac{\ln \left(\frac{S_{t}}{X}\right)+\left(r-r^{*}+\frac{\sigma^{2}}{2}\right) \tau}{\sigma \sqrt{\tau}}\right]-e^{-r \tau} \cdot X \Phi\left[\frac{\ln \left(\frac{S_{t}}{X}\right)+\left(r-r^{*}-\frac{\sigma^{2}}{2}\right) \tau}{\sigma \sqrt{\tau}}\right]
$$

where $S_{t}$ represents the spot forex rate at time $t, \tau$ the time to maturity, $X$ the strike price and $\Phi($.$) is the standard cumulative normal distribution function.$

Market participants use these formulas even though they do not consider the BlackScholes model a precise description of how exchange rates actually behave. We shall follow this practice and, for the second evaluation strategy, carry out numerical procedures using formula (1) without necessarily agreeing with the model.

There is a one-to-one relationship between the volatility parameter $\sigma$ and the BlackScholes pricing function, for fixed values of the remaining arguments. This allows market prices of calls and puts to be expressed in units of volatility, called the BlackScholes implied (or implicit) volatility. Traders quote options in terms of implied volatility. Prices are determined by the market; the Black-Scholes pricing function simply transforms them from one metric to another, when dealers invert function (1) to calculate an implied volatility. The value obtained becomes an estimate of the riskneutral standard deviation of logarithmic changes in the forward exchange rate.

Exercise prices of over-the-counter currency options are often set equal to the forward exchange rate of like maturity, in which case the option is called at-the-money. The at-the-money, short-maturity (eg: one month, three months) over-the-counter currency options are very often the most liquid derivative instruments (vs the in-themoney, out-the-money or the long-maturity options). For example, in response to a question about USD/DEM calls, the trader might reply that "one-month at-the-money calls are 12 at 12.5", meaning that the trader buys the calls at an implied volatility of 12 vols and sells them at 12.5 vols. If a deal is struck, settlement takes place in currency units. The two counter-parties agree on what the current forward rate is, and thus the 
exercise price, and translate the agreed price from vols to marks per dollar of notional underlying value, by substituting the current spot rate, one-month domestic and foreign interest rates, the contractually-agreed maturity (here, one month), exercise price and vol into the Black-Scholes formula (1).

Figure 3 shows the graph of the implied (one-month) at-the-money volatility computed for the daily series.

\section{A BRIEF REVIEW OF THE METHODS}

Since important and encompassing empirical studies like Hsieh's (1988), forex returns have been recognised to exhibit heteroskedasticity and leptokurticity. Yet, there is no agreement regarding the best process to describe their series. Different models capture, with more or less success, these features. In this paper we work with three of them: the GARCH class of models initiated by Bollerslev (1986), the Markovian Switching Models as proposed by Hamilton $(1989,1990)$ and the Cumulative Daily Volatility (cdVol) models based on tick data developed by Zhou (1996 a, b). The first two are full statistical models, suitable to daily observations. The last one is a procedure which, from intraday data, produces an estimate of daily volatilities.

\subsection{The GARCH models}

The GARCH class has become very popular in finance for modelling time varying volatility in forex markets, Bollerslev et al. (1992), Bollerslev et al. (1993). It provides a parsimonious representation which portrays well the volatility cluster effect; however, it builds up a deterministic rather than a stochastic function of past information and does not account for the possibility that either some latent factors or the distribution generating the returns change. Indeed, it is this rather inertial characteristic of its models that is responsible for their most inconvenient properties. ${ }^{2}$

Perhaps the most widely used member of this large family is the $\operatorname{GARCH}(1,1)$ model which has the form:

$$
\mathbf{r}_{\mathrm{t}}=\theta+\sigma_{\mathrm{t}} \varepsilon_{\mathrm{t}} \quad, \quad \varepsilon_{\mathrm{t}} \mid \mathbf{I}_{\mathrm{t}-1} \sim \mathrm{N}(0,1) \quad \text { and }
$$

\footnotetext{
2 For a further criticism on the ARCH/GARCH family see, for instance, Bera and Higgins (1995), and in a crisis forecasting context - Femandes (1999), Chapter 1, and Flôres (1996).
} 


$$
\sigma_{t}^{2}=\omega+\alpha y_{t-1}^{2}+\beta \sigma_{t-1}^{2}
$$

where $r_{t}$ is the natural logarithm rate of return; $\theta$ is the expected return conditional on $I_{t-1}$, the market information available at time $t-1 ; \sigma_{t}^{2}$ is the variance at time $t$ of the prediction error conditional on $I_{t-1}$, and $\omega, \alpha, \beta$ are real coefficients, assumed non negative.

For stability of the volatility process, the sum of $\alpha$ and $\beta$ must be less than one. Moreover, from (2), it is immediate to see that:

$$
\mathbf{r}_{\mathrm{t}} \mid \mathrm{I}_{\mathrm{t}-1} \sim \mathrm{N}\left(\theta, \sigma_{\mathrm{t}}^{2}\right)
$$

Figure 1. Intra-day pattern USD /DEM (Average number of transactions per hour)

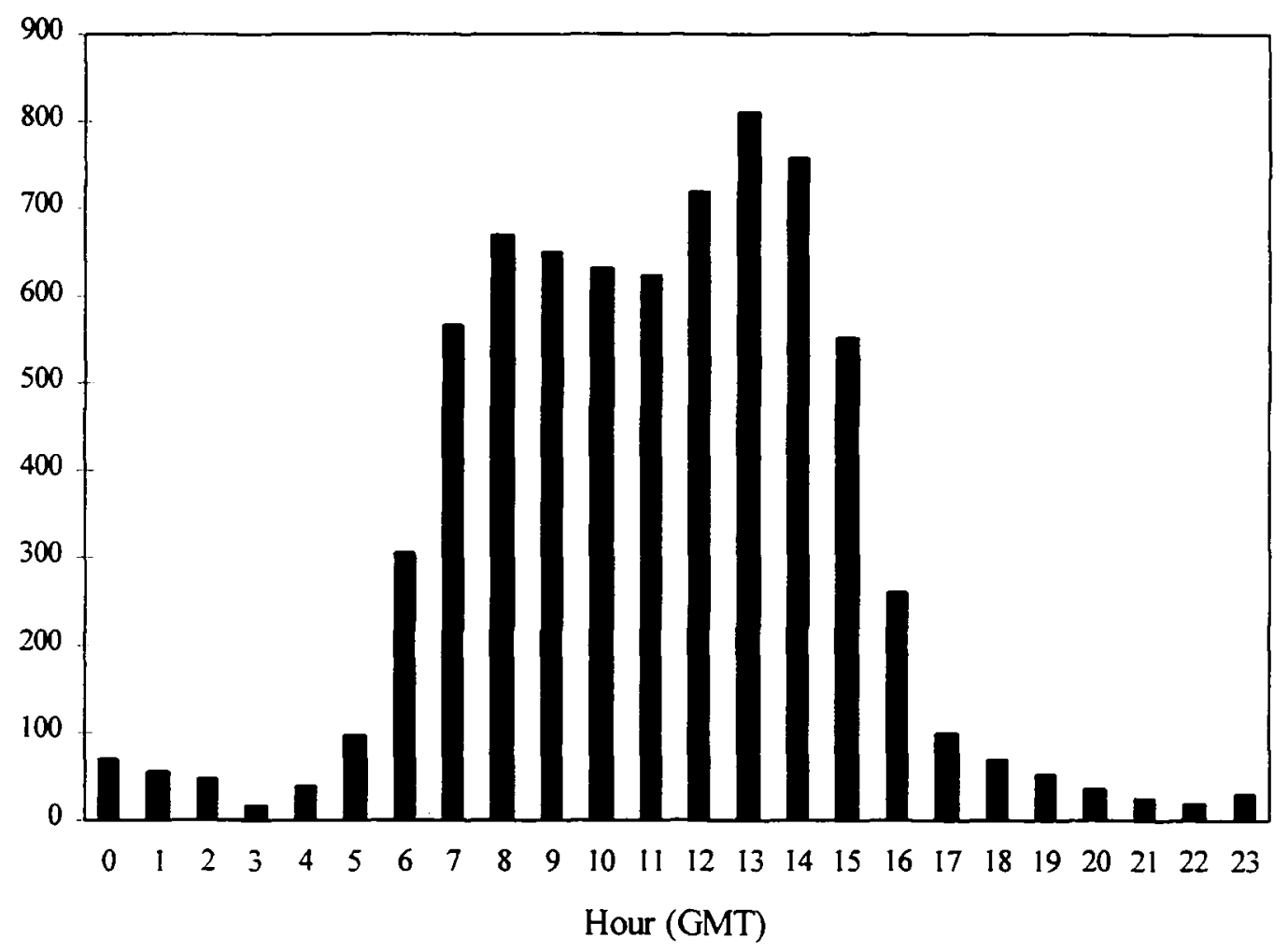

\subsection{The Markovian Switching models}

The volatility switching models, inspired in earlier work by Goldfeld and Quandt (1973) and successfully tested by Rockinger (1994) on stocks, describe returns as being generated by a mixture of normal distributions, where the switch between the 
distributions is determined in a Markovian manner. Volatility becomes then a stochastic function of past information. Though the number of regimes is arbitrary, the model becomes cumbersome and sometimes difficult to work with when allowing for more than three states.

Figure 2. Intra-week pattern USD/DEM (Average number of transactions per day-ofthe-week)

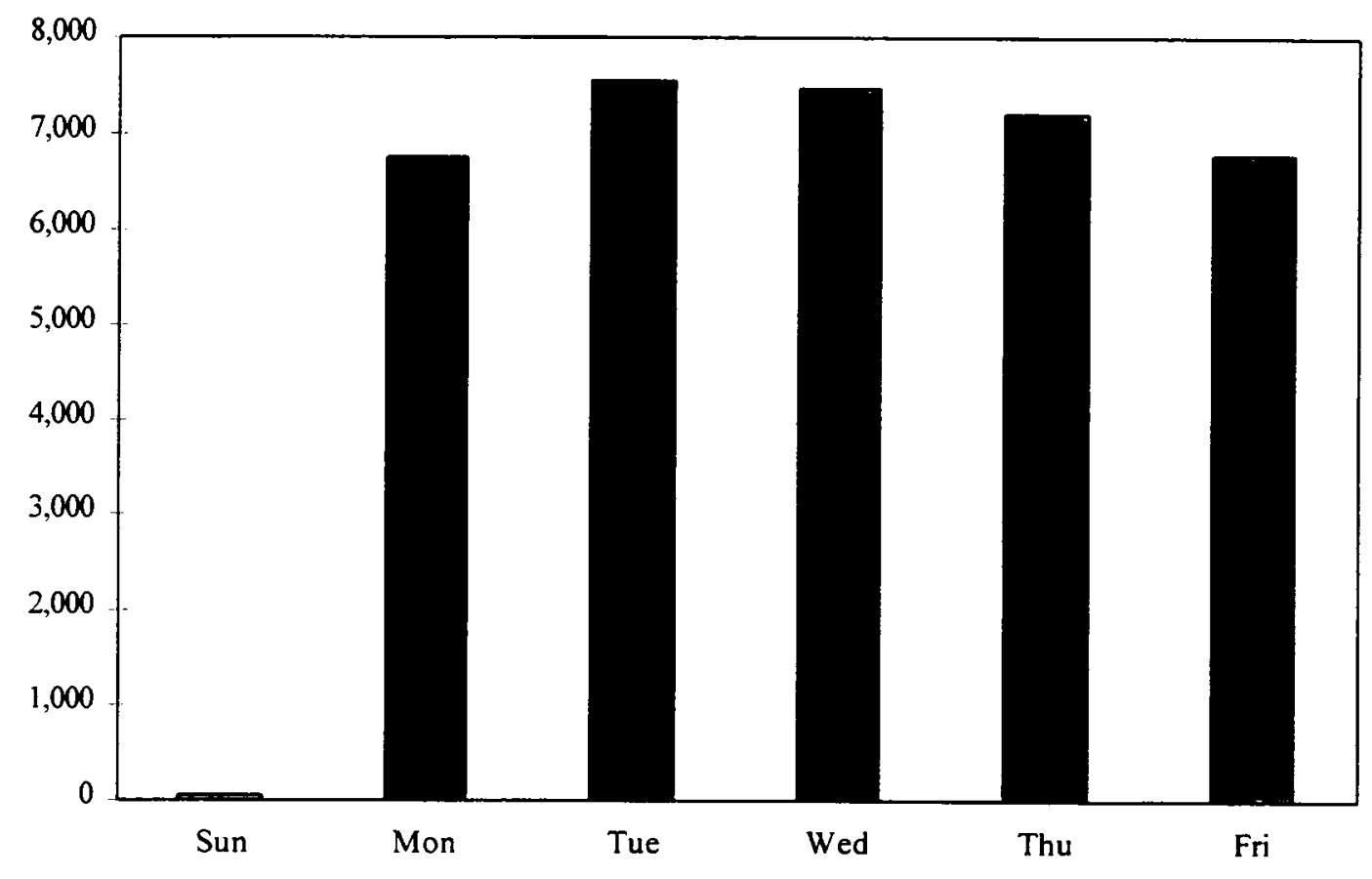

Returns are accordingly modelled as switching processes whose shocks are independent from the states. The shocks are usually drawn from a normal $N(0,1)$ distribution. Assuming, as in this paper, that the variance can switch between only two different regimes, we can write the following equations:

$$
r_{t}=\theta+\left[\sigma_{1} C_{t}+\sigma_{0}\left(1-C_{t}\right)\right] \varepsilon_{t} \quad \text { with } \quad \varepsilon_{t} \text { iid } \sim N(0,1)
$$

where $\sigma_{0}$ and $\sigma_{1}$ represent the values of the two unconditional volatility regimes, $\left\{C_{t}\right\}$ is a Markov chain with values in $\{0,1\}$ and transition probabilities $\left\{\mathrm{p}_{00} . \mathrm{p}_{10} . \mathrm{p}_{01 .} \mathrm{p}_{11}\right\}$ such that :

$$
P\left[C_{t}=i \mid C_{t-1}=j\right]=p_{i j} \quad, \quad i, j=0,1 \quad \text {, with }
$$




$$
\mathrm{p}_{11}+\mathrm{p}_{01}=1 \quad \text { and } \quad \mathrm{p}_{10}+\mathrm{p}_{00}=1
$$

\subsection{The Cumulative Daily Volatility model (cdVol)}

The third technique has been made possible thanks to the increasing power of computers, which has allowed the development of means of storing and dealing with high frequency financial data. These new information technologies opened the possibility to study volatility in greater detail, Dunis (1989), Pictet et al. (1992).

In high frequencies, heteroskedasticity usually increases with the sampling frequency, due to the fact that the variance of the noise inherent to the recording process becomes comparable (even greater than) to the one among the different observed returns, Zhou (1996b). A way to deal with this is to analyse observations at unequally spaced time periods. The procedure of de-volatilisation developed by Zhou (1995) suggests taking more observations in volatile periods and less in quieter ones. This process of obtaining time series with constant volatility re-scales time in a adaptive fashion; the picking frequency or, the time interval between two observations, adjusts to the instantaneous volatility observed tick-by-tick.

Another way to deal with heteroskedasticity, in equally spaced time series as in this paper, is to normalise the returns by their daily cumulative volatility ( $\mathrm{cdVol}$ ). In this case, each daily cumulative volatility is computed from tick-by-tick intraday data within a 24-hour period.

The de-volatilisation and normalisation algorithm developed by Zhou (1996 a, b) is based on a volatility estimator which, from high-frequency tick data, computes the cumulative daily volatility for a set period, say a day or a week. The formula for daily volatility is (Zhou (1996 a)):

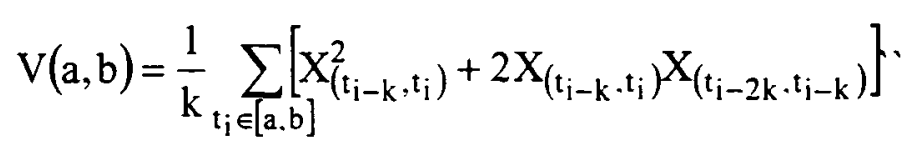

where $X(s, t)=S(t)-S(s)$, is the return of the $(\log )$ spot price observations $S(t)$. The constant $\mathrm{k}$, defining a (systematic) re-sampling interval for the original tick series, must be carefully determined. This is exactly because, as mentioned above, in the presence of significant noise, fewer data are in principle better than more data. Finally, the time extremes $a, b$ are chosen so that $V(a, b)$ computes daily cumulative volatility. 


\section{THE EVALUATION STRATEGY}

In the first two models previously discussed, the residuals should be normal and noncorrelated, in the last one, standardised returns should follow a normal distribution. However, as can be seen from (3) and (4), conveniently standardised returns in the first two models should also be iid $N(0,1)$. The same could be expected if returns are standardised by the implicit volatility. This fact provides a common ground for statistically comparing all models at stake, and our first evaluating criterion consists in a thorough residuals, i.e. standardised returns, analysis, testing all normality assumptions. For the latter, to make things easily reproducible, we have used the two common Jarque-Bera, Jarque and Bera (1980), and Kolmogorov-Smirnov tests.

Evaluation also comprises checking the volatility models through their performance in a volatility hedging strategy. As known in these cases, Gavridis and Dunis (1998), if the volatility estimate is higher than the implied volatility (plus a volatility threshold of say $1 \%$ ) one should go long on the volatility, going short otherwise. If the difference between the "filtered" volatility estimate and the implied volatility is, in absolute value, no greater than the given volatility threshold (here $1 \%$ ), stay neutral. In this example, the position should be kept until the option expires. The figure of merit in this evaluation strategy is the amount of money made or loss (in our case, the amount of Deutsche Marks) at the option's expiry date. In other words, the result is the difference between the strike price and the spot price at the option's expiry. In order to have a background comparison, a random strategy and systematic - long and short - strategies were also used.

\section{THE EMPIRICAL RESULTS}

\subsection{Basic statistics.}

Table 2 shows the results of the $\operatorname{GARCH}(1,1)$ estimation, obtained through maximum likelihood $(\mathrm{ML})$ under the normality assumption for the residuals. The key coefficients $(\alpha$ and $\beta$ ) are significant at $1 \%$, though there is strong evidence that the process is integrated $(\alpha+\beta=0.988)$.

Table 3 shows the estimates for the Markov switching model, obtained in a recursive way, also via $\mathrm{ML}$, under normality for the errors, and supposing two volatility 
regimes. All coefficients are significant at $5 \%$. The probability of staying in the higher volatility regime $\left(C_{t}=0\right)$ is 0.8049 , what means that, on average, it lasts for about five days $(1 /(1-0.8049)=5.13$; see also Hamilton $(1989))$.

For computing the $\mathrm{cdVol}$, the values were obtained on a daily basis. Day $\mathrm{t}$ begins at 10:00 pm and ends 24 hours later (the first day is October 1st, 1995). Intraday observations during day $t$ are denoted by $t_{i}, i=0,1,2, \ldots$. At the beginning of the day, the first intraday observation has value $\mathrm{S}\left(\mathrm{t}_{0}\right)$, and the corresponding initial value of the cumulative daily volatility, $\operatorname{cdVol}(0)$, is zero. Assume now that, in the current day $t$, the most recent element of the tick series is obtained at time $t_{i}: S\left(t_{i}\right)$. One then estimates:

- the volatility increment $\mathrm{V}\left(\mathrm{t}_{\mathrm{i}-1}, \mathrm{t}_{\mathrm{i}}\right)$ using formula (6) described in section 3 , and setting, as in Zhou (1998), the parameter $\mathrm{k}$ for the optimal standard error (in this study, $\mathrm{k}=7$ );

- the updated cumulative volatility within the 24-hour period (ie: until $t_{i}$ does not exceed 10:00 pm of the following trading day) as follows:

$$
\operatorname{cdVol}(\mathrm{i})=\operatorname{cdVol}(\mathrm{i}-1)+\mathrm{V}\left(\mathrm{t}_{\mathrm{i}-1}, \mathrm{t}_{\mathrm{i}}\right)
$$

Table 2. GARCH(1,1): Empirical Results.

\begin{tabular}{|c|c|c|c|c|}
\hline & Value & Std. Error & t Value & $\operatorname{Pr}(>\mathrm{t})$ \\
\hline$\theta$ & $0.02 \mathrm{E}-2$ & 0.00019 & 1.0 & 0.16 \\
\hline$\omega$ & $3.42 \mathrm{E}-7$ & 0.00000 & 1.8 & 0.04 \\
\hline$\alpha$ & 0.019 & 0.00748 & 2.5 & 0.01 \\
\hline$\beta$ & 0.969 & 0.01287 & 75.3 & 0.00 \\
\hline
\end{tabular}

Table 3. Markov switching model - results.

\begin{tabular}{|c|c|c|c|c|}
\hline & Value & Std. Error & $\mathrm{t}$ Value & $\operatorname{Pr}(>\mathrm{t})$ \\
\hline$\theta$ & 0.0345 & 0.0171 & 2.023 & 0.0215 \\
\hline$\sigma_{0}$ & 0.6351 & 0.0281 & 22.603 & 0.0000 \\
\hline$\sigma_{1}$ & 0.2486 & 0.0313 & 7.934 & 0.0000 \\
\hline $\mathrm{p}_{00}$ & 0.8049 & 0.0620 & 12.976 & 0.0000 \\
\hline $\mathrm{p}_{11}$ & 0.6348 & 0.0927 & 6.848 & 0.0000 \\
\hline
\end{tabular}


The cdVol(i) value obtained for the last observation of day $t$ will be the cumulative daily volatility estimate (of the day).

Figure 3 is a graphical summary of the volatilities estimated by the three methods, together with the implicit volatility series computed as described in section 2 . During most of the period under study the implied volatility is superior to the three other estimates.

Figure 3. Volatility estimates, various techniques.

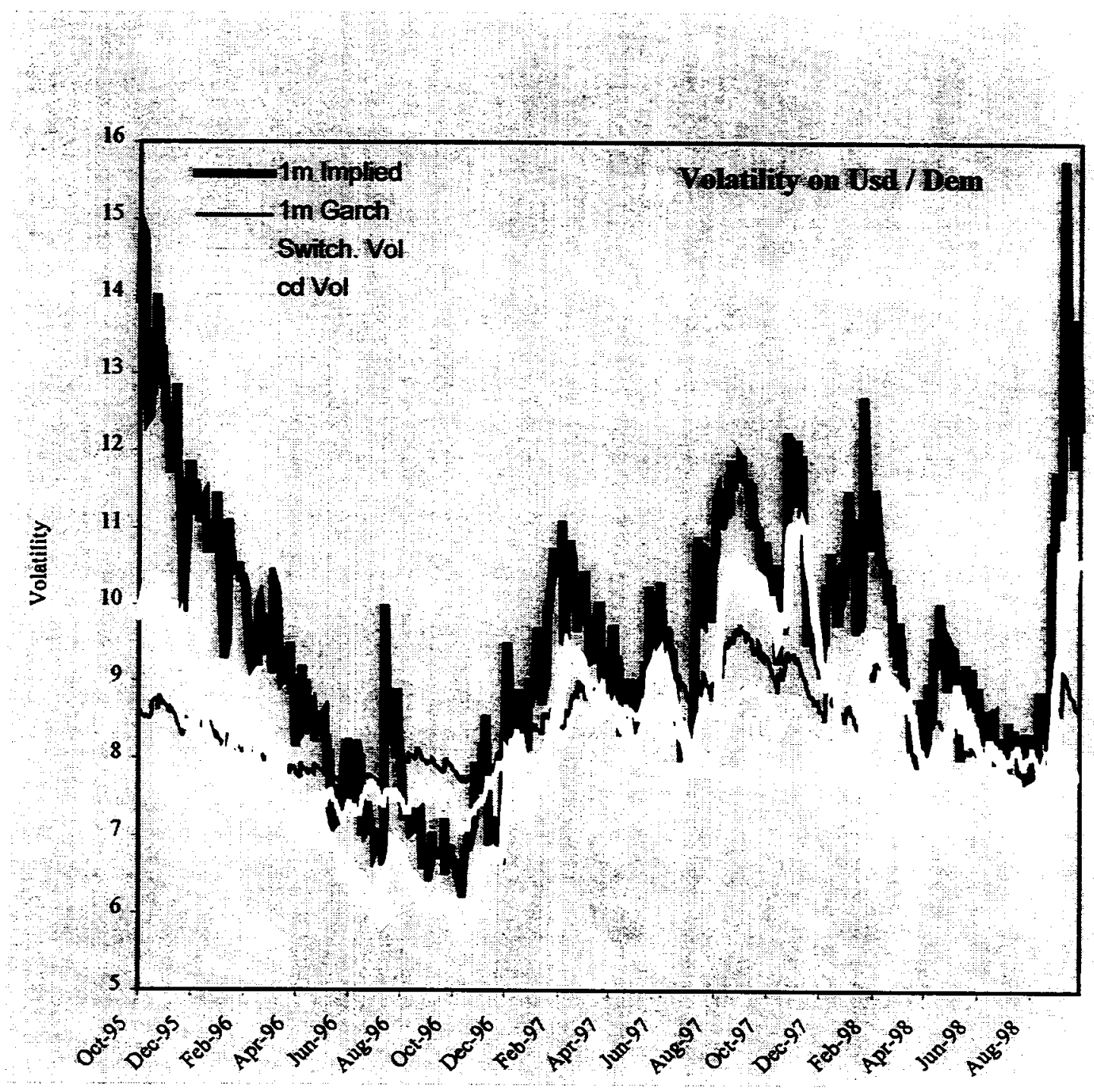




\subsection{Residuals Analysis}

We now carry out a brief analysis of the residuals computed from the four models: the implied volatility model, the GARCH model, the Markovian switching model with two volatility regimes and the cumulative daily volatility model (cdVol). Strictly speaking, the term residuals - as explained in the previous section - is here used for the series of standardised returns. Standardisation uses the forecasted volatilities and according to the case - other parameters in the model as well. If the volatility captures well the fluctuations of the market, and the models' assumptions are valid, such "residuals" are expected to be normal.

Table 4 presents the basic summary statistics and normality tests for the standardised log-returns and the standardised residuals/returns computed from the four procedures. Figures 4 to 6 show the probability plots of the standardised returns from the GARCH( $(1,1)$, the Switching and the cdVol models.

Table 4. Residuals from the five models - basic statistics and normality tests.

\begin{tabular}{|l|l|l|l|l|l|}
\hline & $\begin{array}{l}\text { raw } \\
\log \text { returns }\end{array}$ & $\begin{array}{l}\text { implied } \\
\text { volatility } 1 \mathrm{~m}\end{array}$ & $\begin{array}{l}\text { garch(1,1) } \\
\text { volatility }\end{array}$ & $\begin{array}{l}\text { markovian } \\
\text { switching }\end{array}$ & $\begin{array}{l}\text { cum. daily. } \\
\text { volatility }\end{array}$ \\
\hline
\end{tabular}

\begin{tabular}{|l|r|r|r|r|r|}
\hline Mean & 0.0043 & 0.0425 & 0.0454 & 0.0485 & 0.0879 \\
\hline Std. Dev. & 0.9944 & 0.9218 & 0.9708 & 1.0804 & 0.9525 \\
\hline Skewness & -0.2455 & -0.3257 & -0.2191 & -0.1344 & 0.1031 \\
\hline exc. Kurtosis & 1.2764 & 2.0871 & 0.8518 & 1.2228 & -0.1167 \\
\hline Sample Size & 783 & & & & \\
\hline
\end{tabular}

Ljung-Box(20 lags) critical value at $5 \%=31.4$

\begin{tabular}{|l|r|r|r|r|r|}
\hline - raw std residuals & 25.33 & 22.4 & 23.5 & 23.6 & 21.5 \\
\hline - squared std residuals & 43.82 & 12.2 & 13.8 & 16.9 & 14.8 \\
\hline
\end{tabular}

Normality Tests

\begin{tabular}{|r|r|r|r|r|r|}
\hline Jarque \& Bera & 58.68 & 149.99 & 28.79 & 49.18 & 1.76 \\
\cline { 2 - 7 } & $* * *$ & $* *$ & $* * \neq$ & $* * *$ \\
Kolmogorov Smirnov & 0.0607 & 0.0553 & 0.0502 & 0.0570 & 0.0226 \\
\cline { 2 - 6 } & & & & & \\
\cline { 2 - 6 } p. value & 0.0000 & 0.0000 & 0.0001 & 0.0000 & 0.5000 \\
\hline
\end{tabular}

*** denotes parameter estimates statistically significant at the one percent level

The striking feature is that all models capture fairly well the heteroskedasticity of the underlying time series (as shown by the Ljung-Box test on the squared residuals ) 
Figure 4. Probability plot of the GARCH(1,1) model.

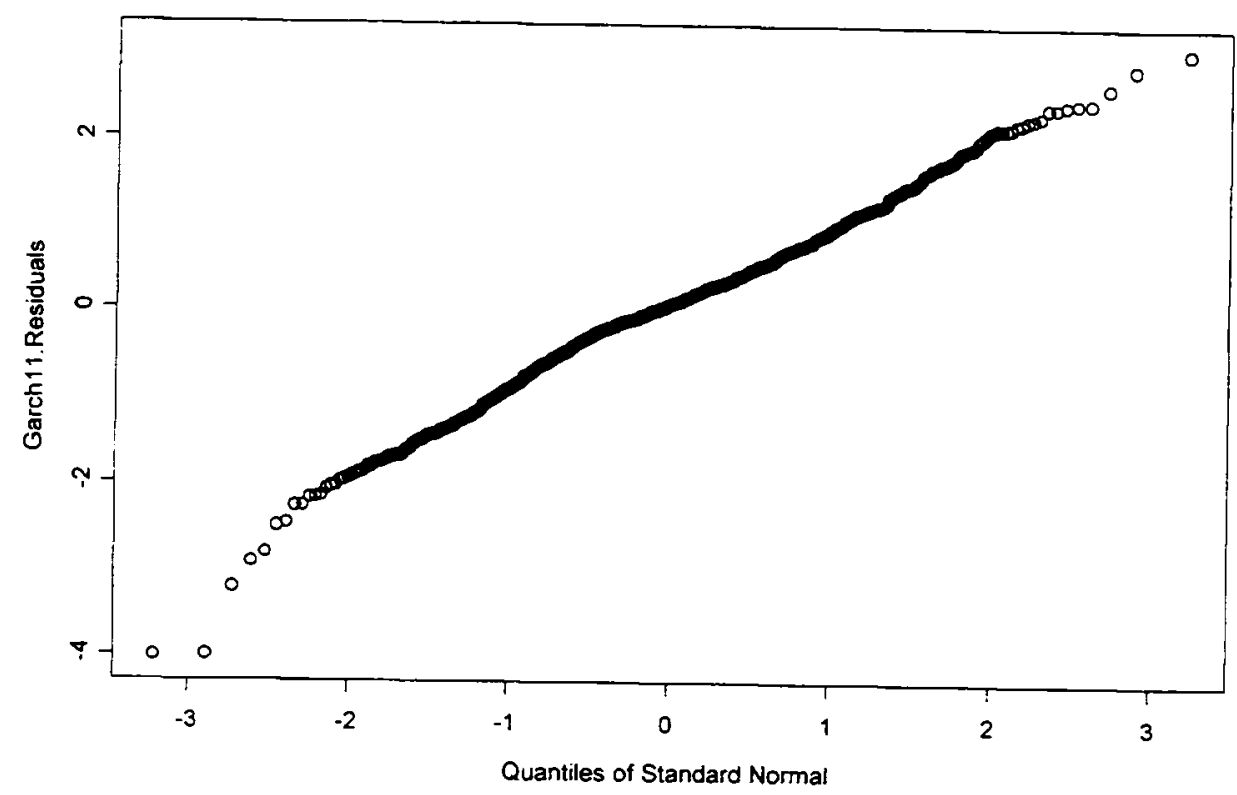

Figure 5. Probability plot of the Markov switching model.

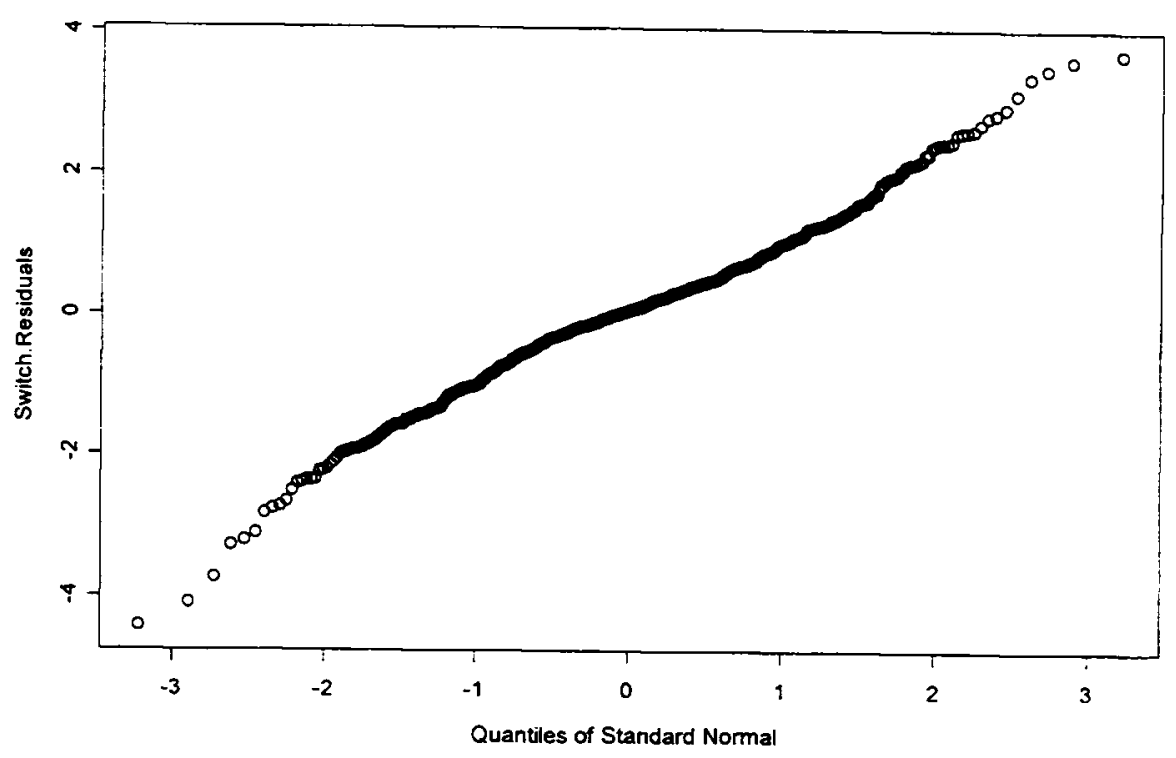


Figure 6. Probability plot of the cdVol Model residuals

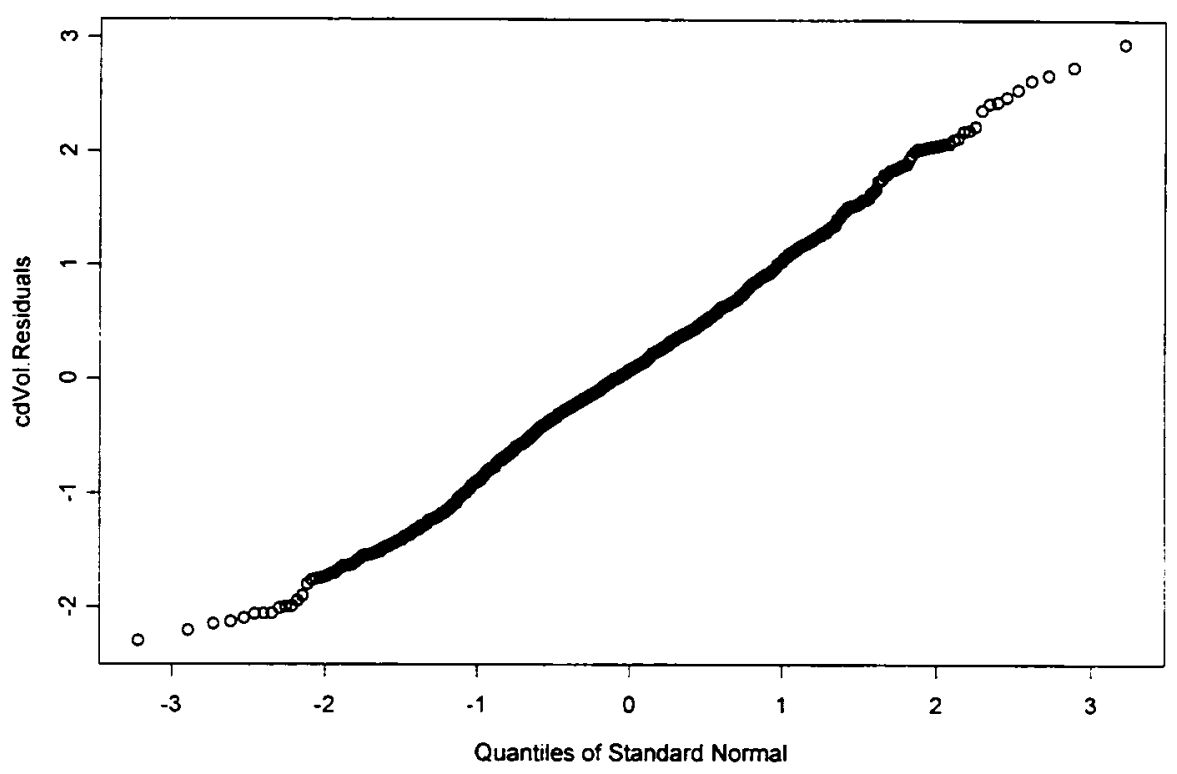

\subsection{Volatility estimates analysis via Volatility Hedging Strategies}

As previously said, if the filtered volatility estimate is greater than the implicit volatility (plus the volatility threshold), one goes long in the volatility; if the filtered volatility estimate is smaller than the implicit volatility (minus the volatility threshold), one goes short; staying neutral otherwise; and keeping the position until the option expires.

We here compare hedging strategies using the $\operatorname{GARCH}(1,1)$, the Markov Switching and the cdVol estimated volatilities. In order to have a set of background values, a random strategy, a systematic short strategy (ie: go short every day) and a systematic long strategy (ie: go long every day) were used.

Table 5 shows the numerical results. We see that systematic profits can be made by trading short volatility, denoting inefficiency periods in the options market. Strategies based on the Switching and the cdVol models outperform the short (and consequently the long and random) strategy, though not to a great extent. In terms of the Risk Reward Ratio, the cdVol hedge is superior to all other strategies. 
Table 5. Summary results of options strategies.

\begin{tabular}{|c|c|c|c|c|c|c|}
\hline & Garch $(1,1)$ & Switching & colvol & Short & Long & Random \\
\hline Tofal ProfiL oss (fin Dem) & 1.52 & 2.89 & 3.17 & 2.11 & -51.10 & -18.60 \\
\hline A Werage Pof T L oss per year & 0.51 & 0.96 & 1.06 & 0.70 & -17.03 & -6.20 \\
\hline Alaximum Draw Down & 2.47 & 1.22 & 1.15 & 2.22 & NA & $\overline{\mathrm{NA}}$ \\
\hline Number of Trades & 361 & 431 & 370 & 782 & 782 & 603 \\
\hline Risk Reward Ratio * & 4.88 & 1.27 & 1.09 & 3.16 & NA & NA \\
\hline
\end{tabular}

* Here defined as the ratio Maximum Drawdown / Average Profit per Year.

Figure 7 displays the daily profit \& loss trajectories for the four hedging strategies which showed positive profits. During most of the time span the cdVol curve dominates the other three. The figure also suggests a somewhat poor performance for the GARCH strategy.

\section{CONCLUSIONS}

We studied the behaviour of three popular volatility models in a USD/DEM daily forex series. In terms of residuals analysis, the cdVol model best captured the normality structure of returns, according to the two goodness-of-fit tests used. GARCH and Markovian residuals presented a somewhat high excessive kurtosis and failed to pass them.

When compared within a hedging framework, all strategies showed positive results and outperformed a random strategy, though the cdVol and the Switching Volatility strategies performed slightly better, with the GARCH hedge failing to beat a short strategy. The fact that a constant short volatility strategy generated profits denotes periods of market inefficiencies.

As a further extension, an economic interpretation of these results should be considered. The existence of long-lasting periods of inefficiencies in a very liquid derivative market and the similar behaviour of the volatility modelling techniques, during periods of the hedging experiment - even though, in almost all terms, the cdVol model was superior - are issues that deserve more attention. 
Figure 7. Graphical Results (daily profit \& loss curve).

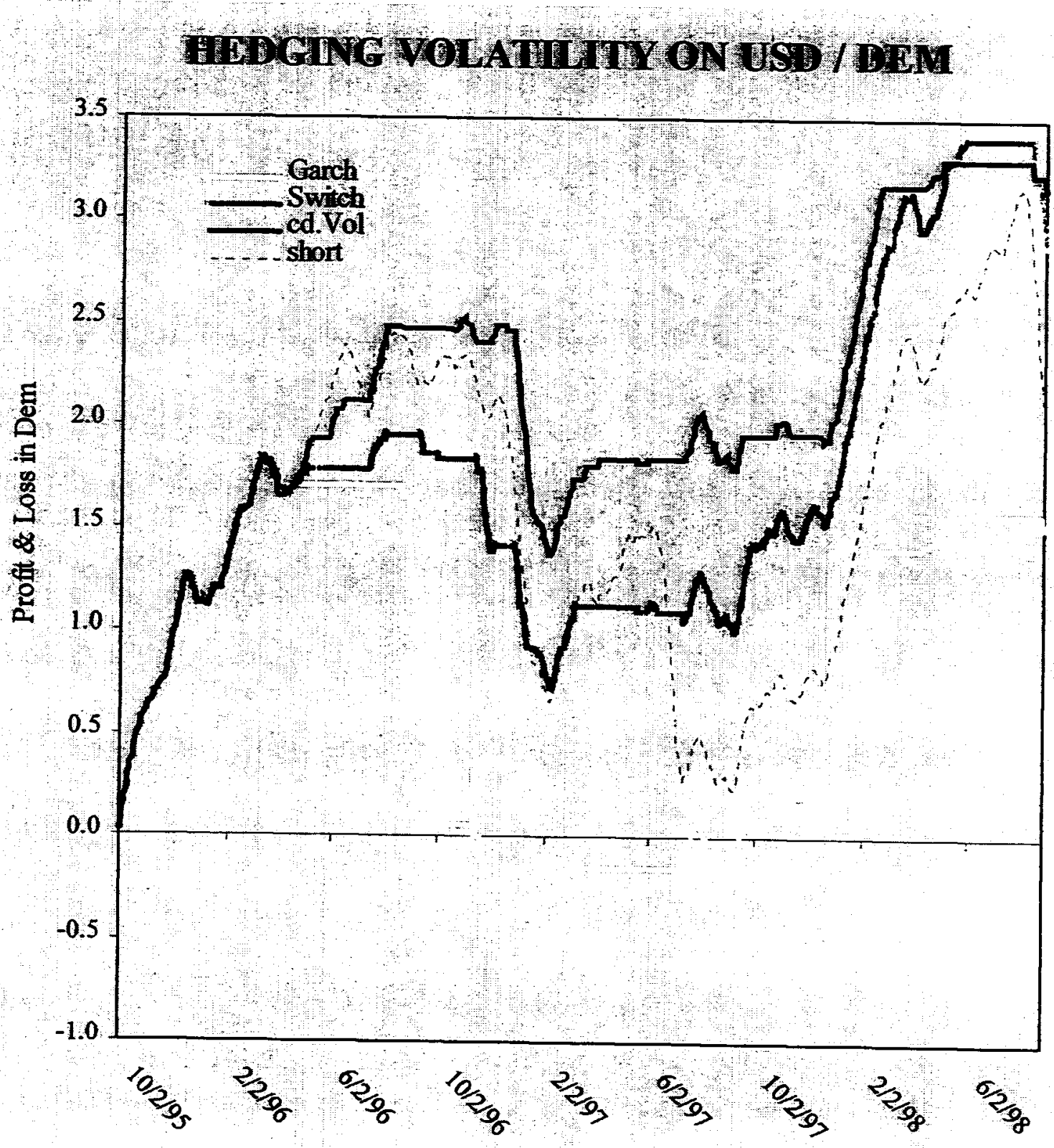

In a more technical note, ARMA models could be developed for the cdVol estimates. This could achieve, in a consistent fashion, the smoothing of the cdVol estimates' uneven development and provide short term forecasts of cdVol. The latter could be a proxy for implied volatility. 
Finally, this comparison framework should be tried in other, non-continuous trading markets, as those for stocks and interest rates. This would shed more light on the points raised here and help in choosing among the three techniques considered.

\section{REFERENCES}

Baillie R. and T. Bollerslev (1989), 'Intra-day and inter-market volatility in exchange rates' Review of Economic Studies 58, 565-585.

Bera, A K. and M. L. Higgins (1995), 'On ARCH Models: Properties, Estimation and Testing', in L. Exley, D. A. R. George, C. J. Roberts and S. Sawyer [eds.], Surveys in Econometrics, Basil Blackwell, Oxford.

Black F. and M. Scholes (1973), 'The pricing of Options and Corporate Liabilities', Journal of Political Economy 81, 637-59.

Bollerslev T. (1986), 'Generalized Autoregressive Conditional Heteroskedasticity', Journal of Econometrics 31, 307-327.

Bollerslev T., R. Chou, K. Kroner (1992), 'ARCH Modeling in Finance: A Review of the Theory and Empirical Evidence', Journal of Econometrics, 52, 5-59.

Bollerslev T., R. Engle, D. Nelson (1993) 'ARCH Models', in R. F. Engle and D.McFadden [eds.], Handbook of Econometrics, Vol. 4, North Holland, Amsterdam.

Campbell J. Y., A. W. Lo and A. C. MacKinlay (1997), 'The Econometrics of Financial Markets', Princeton University Press, Princeton, New Jersey.

Dunis C. (1989), 'Computerised Technical Systems and Exchange Rate Movements', chapter 5, 165-205, in C. Dunis and M. Feeny [eds.], Exchange Rate Forecasting, Probus Publishing Company, Cambridge, UK.

Flôres, R. G., Jr. (1996), 'Crises and Volatility', Proceedings of the $3^{\text {rd }}$ Conference on Forecasting Financial Markets, Imperial College and Chemical Bank, London.

Fernandes, M. (1999), 'Essays on the Econometrics of Continuous-time Finance', Thèse presentée en vue de l'obtention du grade de Docteur en Sciences de Gestion, École de Commerce Solvay, Université Libre de Bruxelles, Bruxelles.

Gavridis, M. and C. Dunis (1998), 'Volatility Trading Models : an application to daily exchange rates', Derivative Use, Trading and Regulation N1, p9-16 
Ghysels, E., C. Gouriéroux and J. Jasiak (1998) 'High frequency financial time series data: some stylized facts and models of stochastic volatility', Chapter III.7 in C. Dunis and B. Zhou [ed], Nonlinear Modelling of High Frequency Financial Time Series, , John Wiley \& Sons, Chichester.

Goldfeld S. and R. Quandt (1973), 'A Markov model for switching regressions', Journal of Econometrics 1, 3-16

Goodhart C. and L. Figliuoli (1991), 'Every minute counts in financial markets' Journal of International Money and Finance 10, 23-52

Guillaume D., M. Dacorogna, R. Davé, U. Müller, R. Olsen and O. Pictet (1997),'From the bird's eye to the microscope: a survey of new stylized facts of the intra-daily foreign exchange markets', Finance and Stochastics 1, 95-129.

Hamilton J. (1989), 'A new approach to the economic analysis of nonstationay time series and the business cycle', Econometrica 57, 357-84.

Hamilton J. (1990), 'Analysis of time series subject to change in regine' Journal of Econometrics 45, 39-70.

Hamilton J. and R. Susmel (1994), 'Autoregressive Conditional Heteroskedasticity and Changes in Regime', Journal of Econometrics 64, 307-333.

Hsieh D. (1988), 'The statistical properties of daily foreign exchange rates: 1974-1983' Journal of International Economics 24, 129-145

Hsieh D. (1989), 'Modeling heteroskedasticity in daily foreign exchange rates' Journal of Business and Economic Statistics 7, 307-317.

Jarque C. M. and A. K. Bera (1980) 'Efficient tests for normality, homoscedasticity, and serial independence regression residuals' Economic Letters 6, 225-259.

Kai J. (1994) 'A Markov Model of Switching-Regime ARCH', Journal of Business \& Economic Statistics, 12, 3, 309-316.

Müller U., M. Dacorogna, D. Davé, R. Olsen, O. Pictet and J. Von Weizsäcker (1997), 'Volatilities of Different Time Resolutions - Analyzing the Dynamics of Market Components', Journal of Empirical Finance 4, no. 2-3, 213-240.

Pictet O., U. Müller, R. Olsen and J. Ward (1992), "Real-Time Trading Models for Foreign Exchange Rates", The Journal of Neural and Mass-Parallel Computing and Information Systems, Neural Network World 2, no. 6, 713-725.

Rockinger M. (1994) 'Regime switching: evidence for the French stock market', Working paper, HEC School of Management, Paris 
Schnidrig R. and D. Würtz (1995), 'Investigation of the volatility and autocorrelation function of the USD/DEM exchange rate on operational time scales', Paper presented at the 'High Frequency Data in Finance' Conference (HFDF-I), Zürich.

Zhou B. (1995), 'High Frequency Data and Volatility in Foreign Exchange Rate', Working paper 3739, MIT Sloan Schoold of Management, Mass.

Zhou B. (1996a), 'Forecasting foreign exchange rates subject to devolatilization', chapter 3, 51-67, in C. Dunis [ed.], Forecasting Financial Markets, John Wiley \& Sons, Chichester.

Zhou B. (1996b), 'High Frequency Data and Volatility in Foreign Exchange Rates', Journal of Business and Economics Statistics, 14, 45-52.

Zhou B. (1998), 'F-consistency, De-Volatilization and Normalization of High Frequency Financial Data', Chapter II.6 in C. Dunis and B. Zhou [ed], Nonlinear Modelling of High Frequency Financial Time Series, , John Wiley \& Sons, Chichester. 


\section{ENSAIOS ECONÔMICOS DA EPGE}

336. TIME-SERIES PROPERTIES AND EMPIRICAL EVIDENCE OF GROWTH AND INFRASTRUCTURE (REVISED VERSION) - João Victor Issler e Pedro Cavalcanti Ferreira - Setembro 1998 - 38 pág.

337. ECONOMIC LIFE OF EQUIPMENTS AND DEPRECIATION POLICIES - Clovis de Faro - Outubro 1998 - 18 pág.

338. RENDA PERMANENTE E POUPANÇA PRECAUCIONAL: EVIDÊNCIAS EMPÍRICAS PARA O BRASIL NO PASSADO RECENTE (VERSÃO REVISADA)

- Eustáquio Reis, João Victor Issler, Fernando Blanco e Leonardo de Carvalho Outubro 1998 - 48 pág.

339. PUBLIC VERSUS PRIVATE PROVISION OF INFRASTRUCTURE - Pedro Cavalcanti Ferreira - Novembro 1998 - 27 pág.

340. "CAPITAL STRUCTURE CHOICE OF FOREIGN SUBSIDIARIES: EVIDENCE FORM MULTINATIONALS IN BRAZIL"- Walter Novaes e Sergio R.C.Werlang Dezembro 1998 - 36 pág.

341. THE POLITICAL ECONOMY OF EXCHANGE RATE POLICY IN BRAZIL: 1964-1997 - Marco Bonomo e Cristina Terra - Janeiro 1999 - 46 pág.

342. PROJETOS COM MAIS DE DUAS VARIAÇÕES DE SINAL E O CRITÉRIO DA TAXA INTERNA DE RETORNO - Clovis de Faro e Paula de Faro - Fevereiro 1999 - 31 pág.

343. TRADE BARRIERS AND PRODUCTIVITY GROWTH: CROSSINDUSTRY EVIDENCE - Pedro Cavalcanti Ferreira e José Luis Rossi Março 1999 - 26 pág.

344. ARBITRAGE PRICING THEORY (APT) E VARIÁVEIS MACROECONÔMICAS - Um Estudo Empírico sobre o Mercado Acionário Brasileiro - Adriana Schor, Marco Antonio Bonomo e Pedro L. Valls Pereira Abril de 1999 - 21 pág.

345. UM MODELO DE ACUMULAÇÃO DE CAPITAL FÍSICO E HUMANO: UM DIÁlOGO COM A ECONOMIA DO TRABALHO - Samuel de Abreu Pessôa - Versão Preliminar: Abril de 1999 - 24 pág.

346. INVESTIMENTOS, FONTES DE FINANCIAMENTO E EVOLUÇÃO DO SETOR DE INFRA-ESTRUTURA NO BRASIL: 1950-1996 - Pedro Cavalcanti Ferreira e Thomas Georges Malliagros - Maio de 1999 - 42 pág.

347. ESTIMATING AND FORECASTING THE VOLATILITY OF BRAZILIAN FINANCE SERIES USING ARCH MODELS (Preliminary Version) - João Victor Issler - Junho de 1999 - 52 pág. 
348. ENDOGENOUS TIME-DEPENDENT RULES AND INFLATION INERTIA - (Preliminary Version) - Marco Antonio Bonomo e Carlos Viana de Carvalho - Junho de 1999 - 22 pág.

349. OPTIMAL STATE-DEPENDENT RULES, CREDIBILITY, AND INFLATION INERTIA - Heitor Almeida e Marco Antonio Bonomo - Junho de 1999 - 34 pág.

350. TESTS OF CONDITIONAL ASSET PRICING MODELS IN THE BRAZILIAN STOCK MARKET - Marco Bonomo e René Garcia - Julho de 1999 - 35 pág.

351. INTRODUÇÃO À INTEGRAÇÃO ESTOCÁSTICA (Revisado em Julho de 1999) - Paulo Klinger Monteiro - Agosto de 1999 - 65 pág.

352. THE IMPORTANCE OF COMMON-CYCLICAL FEATURES IN VAR ANALYSIS: A MONTE-CARLO STUDY (Preliminary Version) - Farshid Vahid e João Victor Issler - Setembro 1999 - 41 pág.

353. ON THE GROWTH EFFECTS OF BARRIERS TO TRADE - Pedro Cavancanti Ferreira e Alberto Trejos - Setembro 1999 - 31 pág.

354. FINANCE AND CHANGING TRADE PATTERNS IN BRAZIL - Cristina T. Terra - Setembro 1999 - 45 pág.

355. ECONOMIA REGIONAL, CRESCIMENTO ECONÔMICO E DESIGUALDADE REGIONAL DE RENDA - Samuel de Abreu Pessôa Setembro de 1999 - 9 pág.

356. ECONOMIA REGIONAL E O MERCADO DE TRABALHO - Afonso Arinos de Mello Franco Neto - Setembro de 1999 - 26 pág.

357. "WE SOLD A MILLION UNITS" - THE ROLE OF ADVERTISING PASTSALES - Paulo Klinger Monteiro e José Luis Moraga-González - Outubro de 1999 - 28 pág.

358. OPTIMAL AUCTIONS IN A GENERAL MODEL OF IDENTICAL GOODS - Paulo Klinger Monteiro - Outubro de 1999 - 17 pág.

359. DISCRETE PUBLIC GOODS WITH INCOMPLETE INFORMATION Flavio M. Menezes, Paulo Klinger Monteiro e Akram Temimi - Outubro de 1999 - 33 pág.

360. SYNERGIES AND PRICE TRENDS IN SEQUENTIAL AUCTIONS - Flavio M. Menezes e Paulo Klinger Monteiro - Outubro de 1999 - 19 pág.

361. VOLATILITY MODELLING IN THE FOREX MARKET: AN EMPIRICAL EVALUATION - Renato G. Flôres Jr. e Bruno B. Roche - Novembro de 1999 -23 pág. 


\section{FUNDAÇÃOGETULIO VARGAS \\ BIBUOTECA}

ESTE VOLUME DEVE SER DEVOLVIDO A BIBLIOTECA NA ÜLTIMA DATA MARCADA

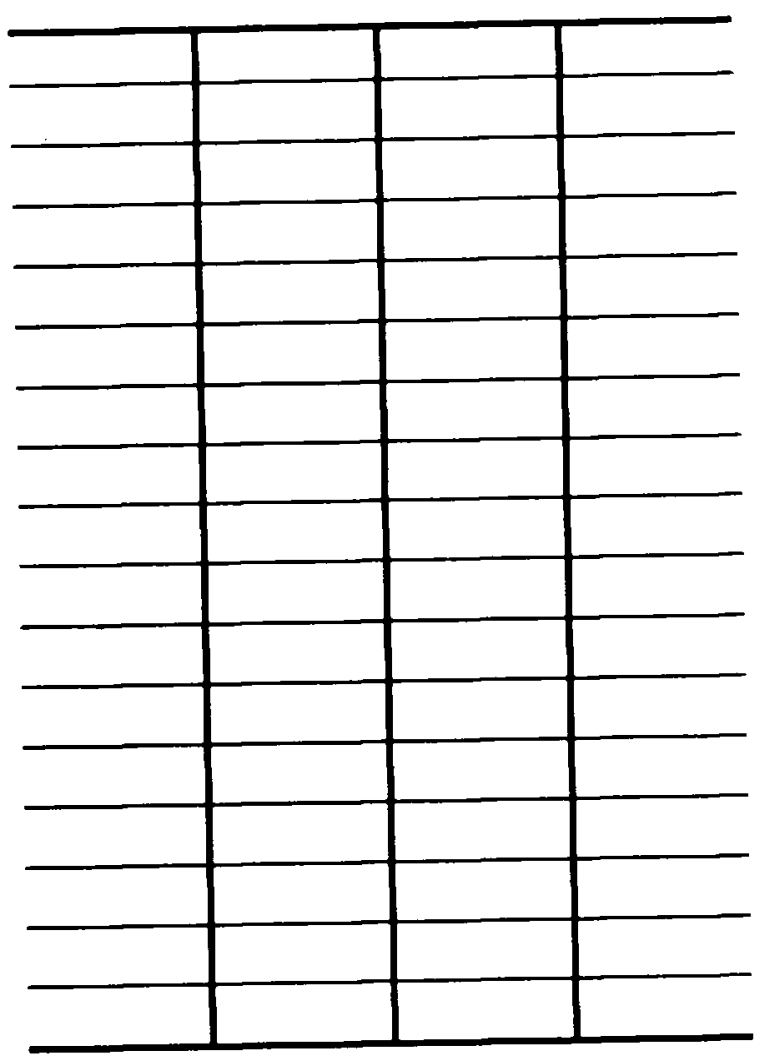

N.Cham. P/EPGE EE 361

Autor: FLÔRES JUNIOR, Renato Galvão

Título: Volatility modelling in the forex market : an empiri | 00090827

53329

FGV - BMHS

$\mathrm{N}^{\mathrm{O}}$ 